Diabetologia 8, 99-103 (1972)

(C) by Springer-Verlag 1972

\title{
Reactivity of the Veins in Diabetes
}

\author{
A. Czẏ̇yK and K. OstrowskI \\ Department III of Internal Diseases, Medical Academy, Warsaw, Poland
}

Received: June 21, 1971, accepted : December 6, 1971

Summary. In 32 patients with juvenile onset diabetes and 32 healthy subjects, venous reflexes were studied by determination of the peripheral venous pressure, forearm blood flow and venous tone at rest and after application of the following stimuli: passive change in the position of the legs, cooling of the opposite forearm, intravenous injection of Bamethan sulfate and of Phentolamine. The changes in the measured parameters induced by spasmolytic drugs were similar in both groups, whereas the effect of a drug blocking the alpha receptors and of the stimuli acting reflexly, was markedly less pronounced in diabetics. -- The present results are interpreted as indicating specific venous changes in diabetes (venopathia diabetica), expressed as a decrease in the venous tone, impairment of the venous reflexes and rise of the venous pressure. The differences of the venous reflexes after blocking of the alpha receptors may indicate that changes in vessel innervation are the primary cause of diabetic venopathy.

\section{Réactivité des veines dans le diabète}

Résumé. On a effectué des recherches sur la réflectivité veineuse chez 32 patients atteints de diabète juvénile et chez 32 sujets sains: on a déterminé la tension veineuse périphérique, le débit sanguin dans l'avant-bras, ainsi que le tonus veineux au repos et après l'application de stimuli tels que le changement passif de la position des jambes, le refroidissement de l'avant-bras opposé, ou l'injection intraveineuse de Baméthane sulfate et de Phentolamine. - On a constaté des modifications semblables dans les paramètres examinés, après avoir administré dans les deux groupes le spasmolytique. Par contre le médicament bloquant les récepteurs alpha adrénergiques et les stimuli agissant par voie réflexe avaient un effet nettement plus faible chez les diabétiques.
- Les résultats obtenus sont interprétés comme indiquant des lésions veineuses spécifiques du diabète s'exprimant par la diminution du tonus veineux, l'affaiblissement des réflexes veineux et l'accroissement de la tension veineuse. Le caractère distinctif des réflexes veineux après le blocage des récepteurs alpha peut parler en faveur de l'hypothèse que la cause primaire de la veinopathie diabétique réside dans les lésions de l'innervation des parois veineuses.

\section{Venenreflexe bei Diabetes}

Zusammenfassung. Bei 32 Patienten mit jugendlichem Diabetes und 32 Gesunden wurden die Venenreflexe bestimmt, welche auf der Änderung des peripheren Venendrucks, der Haut- und Muskeldurchblutung am Unterarm und des Venentonus unter Einwirkung eines passiven Wechsels der Beinposition, der Kühlung des gegenseitigen Unterarms und der i.v. Injektion von Bamethansulfat und Phentolamin beruhen. - In beiden Gruppen fand man eine gleichsinnige Änderung von bestimmten Parametern nach der Verabreichung des Spasmolytikums, dagegen waren bei Diabetikern die Effekte des AlphaReceptor-Blockers und der reflexbedingten Stimuli signifikant sehwächer ausgedrückt. Die festgestellten Ergebnisse, d.h. der herabgesetzte Venentonus, die ab. geschwächten Venenreflexe und der erhöhte Venendruck werden im Sinne einer für den Diabetes mellitus spezifi. schen Venenschädigung (venopathia diabetica) gedeutet. Die Verschiedenheit des Verlaufs der Venenreflexe nach der Alpha-Receptor-Blockade kann auf eine Störung der Innervation der Venenwand als die primäre Ursache der diabetischen Venopathie hinweisen.

Key words: Venpathia diabetica, venous tone, peripheral venous pressure, forearm blood flow.
Specific vascular changes in diabetes, involving the capillaries and small arterial vessels, referred to as diabetic angiopathy, are relatively well known. On the other hand the knowledge of diabetes-induced changes in the venous part of the circulation is scarce (Ditzel 1954; Landau and Davis, 1960; Camerini-Davalos et al., 1963; Taton, 1968; Skovborg et al., 1969; Chazan, 1969; Godlewski and Ostrowski, 1971).

The fact that the venous system is less well known than the arterial part of the circulation is due to the methodological difficulties involved (cf. review by Alexander, 1963, and by Wood, 1965).

The present study was designed to evaluate the hemodynamic changes of the venous system in juvenile onset diabetes by measuring: venous pressure, venous tone and venous reflexes in response to thermal and pharmacological stimuli. Thus, the investigations involve the determination of functional parameters (Sharpey-Schafer, 1963; Shlomo et al., 1966; Christensen, 1969; Hauke et al., 1969), and include no morphologic evaluation.

\section{Material and methods}

The material comprised 32 patients with juvenile onset diabetes treated with insulin. The duration of diabetes ranged from 3 to 8 years. Eight women and 24 men aged from 15 to 40 years were studied. The control group was made up of 32 healthy subjects, 12 women and 18 men aged from 18 to 40 years. Among the diabetics, four patients had evidence of retinopathy, three of nephropathy, two of neuropathy and two mild evidence of arteriosclerosis obliterans. No increase in arterial blood 
pressure was observed either in controls or in diabetics.

The tests were performed in the recumbent position, after about $1 \mathrm{~h}$ rest at a constant room temperature of $22^{\circ} \mathrm{C}$ (range $1-2^{\circ} \mathrm{C}$ ).

In each patient measurement was made of: 1 . total forearm blood flow, 2. venous pressure and 3 . venous tone.

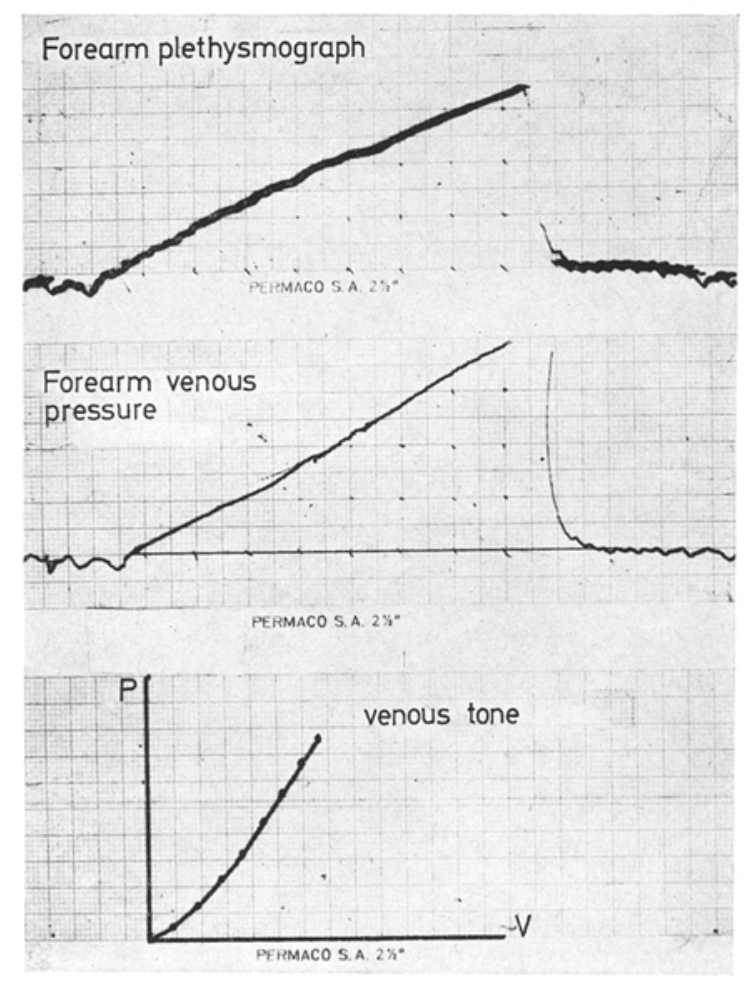

Fig. 1. Curves showing the changes in venous pressure and forearm volume after venous occlusion

The forearm blood flow was measured by our own modification of Whitney's method, using a wire straingauge (tensometric indicator) instead of a mercury-inrubber strain-gauge. The strain-gauge used in this study measures linearly the increase in circumference, to within $0.01 \mathrm{~mm}$, with a mean starting circumference $20-25 \mathrm{~cm}$.

Venous pressure was determined in the antecubital vein, by introducing a polyethylene catheter which was connected by means of low elasticity tubing to a Statham-type electromanometer; for recording, a Sanborn-type polygraph was used. The position of the forearm was maintained at the level of the heart.

Venous tone was calculated from the simultaneously recorded curves describing forearm volume increase and the rise of venous pressure during first 2 sec after venous occlusion. The pressure in the manometer-cuff was about $35 \mathrm{~mm} \mathrm{Hg}$ (Fig. 1).

The effect of various stimuli on the venous vessels was investigated according to the following order:
In all subjects, several initial measurements were taken at rest. Subsequently, changes in the peripheral flow, venous pressure and venous tone induced by passive raising of the lower limbs to a level of about $45^{\circ}$, were determined by performing several measurements every 30 sec. The legs were then lowered, and measurements were repeated every $3 \mathrm{~min}$ until they returned to the initial values.

The next stage involved the measurement of the effect of sudden cooling of the opposite upper limb to about $+16^{\circ} \mathrm{C}$, (skin of the forearm) with ethyl chloride. The above-mentioned parameters were measured 30 sec, 1, 3 and 10 min after completion of cooling.

To determine the effect of drugs on the haemodynamics of the venous system, one half of patients were given intravenously Bamethan sulfate (Vasculat, Boehringer, Ingelheim) in a dose of $1 \mathrm{mg}$ per $\mathrm{kg}$ of body weight over $3 \mathrm{~min}$. The other half were given Phentolamine (Regitin, Ciba, Basel) in a dose of $0.2 \mathrm{mg}$ per $\mathrm{kg}$ of body weight. Measurements of the nvestigated parameters were made 30 sec, 1,3 and $6 \mathrm{~min}$ after completion of drug administration. After this, the response of the venous system to cooling of the opposite upper limb was recorded.

To calculate the changes in the volume $(\Delta V)$, blood flow $(B F)$ and venous tone $(V T)$, the following equations were applied:

$$
\begin{aligned}
& \text { 1. } \Delta V=\frac{2 \cdot \Delta G \cdot V}{G} \\
& \text { 2. } B F=\frac{\Delta V}{\Delta t} \\
& \text { 3. } V T=\frac{\Delta P}{\Delta V}\left[\frac{\mathrm{mmHg}}{\mathrm{ml}}\right]
\end{aligned}
$$

where $V$ - volume of the examined segment

$$
\begin{aligned}
& G \text { - girth of examined segment } \\
& P \text { - pressure } \\
& t=\text { time }
\end{aligned}
$$

The results were expressed as mean \pm standard error; the significance of the differences was evaluated according to Fisher and Yates, for significance level $p<0.01$.

\section{Results}

The mean values of the investigated parameters and the effects of the applied stimuli on the hemodynamics of the venous system are presented in Table 1 .

The resting blood flow through the forearm was significantly higher in the entire control group than in the whole group of diabetics $(p<0.01)$. Passive raising of the lower limbs induced a greater increase in the blood flow in the control group, as compared with the group of diabetics $(p<0.001)$. Cooling of the opposite forearm resulted in a drop in the blood flow in both groups. However the reduction in the blood flow was less in the diabetics, though it persisted longer, showing a slight tendency towards normalisation when compared with the control group. 
After drugs exerting a direct effect on the muscular coat of the vessels (Bamethan sulfate), the increase in the blood flow was somewhat less marked in the diabetios, the difference being insignificant. On the other hand, after drugs blocking the adrenergic alpha receptors (Phentolamine), the increase in the blood flow in diabetics was five times smaller than in controls $(p<0.001)$ (Fig. 2). i.e. a marked drop in tonus of about $40 \%$ relative to the initial value. In consequence to repeated cooling of the opposite limb after injection of Bamethan sulfate: in controls the venous tone re-increased whereas in diabetics the effect was slight. Drugs blocking the alpha receptors induced in controls a pronounced drop in the venous tone, as compared with the values obtained $10 \mathrm{~min}$ after first cooling $(p<0.001)$, while

Table 1. Mean values of the forearm blood flow, venous pressure and venous tone in healthy subjects and diabetics

\begin{tabular}{|c|c|c|c|c|c|c|c|}
\hline \multirow{3}{*}{ Outline of tests } & \multirow{3}{*}{$\begin{array}{l}\text { No of } \\
\text { cases }\end{array}$} & \multicolumn{2}{|c|}{$\begin{array}{l}\text { Forearm flow } \\
\mathrm{ml} / 100 \mathrm{ml} \text { of tissue } / \mathrm{min}\end{array}$} & \multicolumn{2}{|c|}{$\begin{array}{l}\text { Venous pressurea } \\
\text { cm of water }\end{array}$} & \multicolumn{2}{|c|}{$\begin{array}{l}\text { Venous tone } \\
\mathrm{mm} \mathrm{Hg} / \mathrm{ml}\end{array}$} \\
\hline & & Healthy & Diabetics & Healthy & Diabetics & Healthy & Diabetics \\
\hline & & $\mathrm{X} \pm \mathrm{sE}$ & $\mathrm{X} \pm \mathrm{SE}$ & $\mathrm{X} \pm \mathrm{SE}$ & $\mathrm{X} \pm \mathrm{SE}$ & $\mathrm{X} \pm \mathrm{SE}$ & $X \pm S E$ \\
\hline At rest & 32 & $4.6 \pm 0.2$ & $3.7 \pm 0.2^{\mathrm{b}}$ & $11.8 \pm 0.3$ & $13.9 \pm 0.4$ & $1.5 \pm 0.06$ & $1.1 \pm 0.04^{\mathrm{c}}$ \\
\hline $\begin{array}{l}\text { Passive change of } \\
\text { position of legs }\end{array}$ & 32 & $7.5 \pm 0.3$ & $4.6 \pm 0.3^{c}$ & $12.0 \pm 0.4$ & $14.5 \pm 0.3^{\mathrm{c}}$ & $1.3 \pm 0.05$ & $1.2 \pm 0.05$ \\
\hline $\begin{array}{l}\text { Normal resting } \\
\text { position }\end{array}$ & 32 & $5.2 \pm 0.2$ & $3.4 \pm 0.1^{\mathrm{c}}$ & $11.9 \pm 0.3$ & $13.6 \pm 0.5$ & $1.5 \pm 0.06$ & $1.1 \pm 0.04^{\mathrm{c}}$ \\
\hline $\begin{array}{l}\text { After cooling of } \\
\text { opposite forearm } \\
\text { (mean for } 30 \mathrm{sec} \text {, } \\
1 \mathrm{~min} \text { and } 3 \mathrm{~min} \text { ) }\end{array}$ & 32 & $0.9 \pm 0.1$ & $1.6 \pm 0.1$ & $14.1 \pm 0.1$ & $13.9 \pm 0.4$ & $1.9 \pm 0.08$ & $1.2 \pm 0.04^{c}$ \\
\hline 10 min after cooling & 32 & $1.8 \pm 0.1$ & $1.7 \pm 0.1$ & $14.2 \pm 0.4$ & $11.2 \pm 0.3^{\mathrm{c}}$ & $2.6 \pm 0.11$ & $0.8 \pm 0.03^{\mathrm{c}}$ \\
\hline $\begin{array}{l}\text { After Phentolamine } \\
\text { (mean for } 30 \text { sec, } \\
1 \text { min, } 3 \text { min and } 6 \text { min) }\end{array}$ & 16 & $7.0 \pm 0.5$ & $2.6 \pm 0.1^{\mathrm{c}}$ & $12.2 \pm 0.5$ & $10.6 \pm 0.4$ & $1.0 \pm 0.07$ & $0.8 \pm 0.06$ \\
\hline $\begin{array}{l}\text { Cooling (mean for } \\
30 \mathrm{sec}, 1 \mathrm{~min} \text { and } 3 \mathrm{~min} \text { ) }\end{array}$ & 16 & $6.0 \pm 0.3$ & $3.4 \pm 0.2^{c}$ & $11.0 \pm 0.3$ & $11.7 \pm 0.5$ & $0.7 \pm 0.04$ & $0.9 \pm 0.04$ \\
\hline 10 min after cooling & 16 & $4.7 \pm 0.3$ & $3.8 \pm 0.3$ & $10.1 \pm 0.3$ & $10.8 \pm 0.4$ & $0.7 \pm 0.05$ & $0.8 \pm 0.04$ \\
\hline $\begin{array}{l}\text { After Bamethane sul- } \\
\text { fate (mean for } 30 \mathrm{sec}, \\
1 \mathrm{~min}, 3 \mathrm{~min} \text { and } 6 \mathrm{~min} \text { ) }\end{array}$ & 16 & $7.0 \pm 0.5$ & $5.0 \pm 0.4$ & $10.8 \pm 0.4$ & $10.6 \pm 0.4$ & $1.1 \pm 0.05$ & $0.6 \pm 0.03^{c}$ \\
\hline $\begin{array}{l}\text { Cooling (mean for } 30 \\
\text { sec, } 1 \text { min and } 3 \text { min) }\end{array}$ & 16 & $4.0 \pm 0.3$ & $3.8 \pm 0.3$ & $12.0 \pm 0.5$ & $11.0 \pm 0.5$ & $1.4 \pm 0.08$ & $0.7 \pm 0.03^{\mathrm{c}}$ \\
\hline 10 min after cooling & 16 & $4.2 \pm 0.3$ & $3.6 \pm 0.2$ & $12.5 \pm 0.6$ & $10.5 \pm 0.4$ & $1.2 \pm 0.08$ & $0.7 \pm 0.04^{\mathrm{c}}$ \\
\hline
\end{tabular}

a initial values obtained before venous occlusion; $\quad$ b $p<0.01 ; \quad{ }^{c} p<0.001$

The values of the peripheral venous pressure in diabetics were $2 \mathrm{~cm} \mathrm{H_{2 }} O$ higher than in controls, with a slight increase in both groups after passive raising of the lower limbs. Cooling of the opposite forearm induced a much reduced response in the group of diabetics $(p<0.001)$.

The drug with a direct effect on the muscular coat of the vessels caused a closely similar drop in the venous pressure in both groups. The drug blocking the alpha receptors resulted in a marked decrease in venous pressure in controls, as compared with the values obtained $10 \mathrm{~min}$ after first cooling $(p<0.001)$, whereas the effect in diabetics was marginal (Fig. 3).

The initial values of the venous tone were lower in diabetics. The stimuli acting reflexively, viz. passive raising of the legs or cooling of the opposite limb, induced typical changes in controls and but less marked changes in diabetios (Fig. 4). On the other hand, Bamethan sulfate gave in both groups a similar effect, in diabetics their effect was but slight. Repeated cooling of the opposite limb caused no increase in the venous tone in both controls and diabetics (Fig. 5).

\section{Discussion}

While the investigated parameters do not comprehensively cover hemodynamic changes, they permit us to observe the response of the venous system to some stimuli. By measuring the arterial inflow into the segment of limb and observing the changes in venous pressure and volume (the latter being almost completely related to the changes in the blood volume within the venous system) the tone and distensibility of this system can be determined. The results obtained for the forearm blood flow indicate that in diabeties at rest, this flow is on the average smaller than in healthy subjects, while the individual values remain within the "normal" range. 


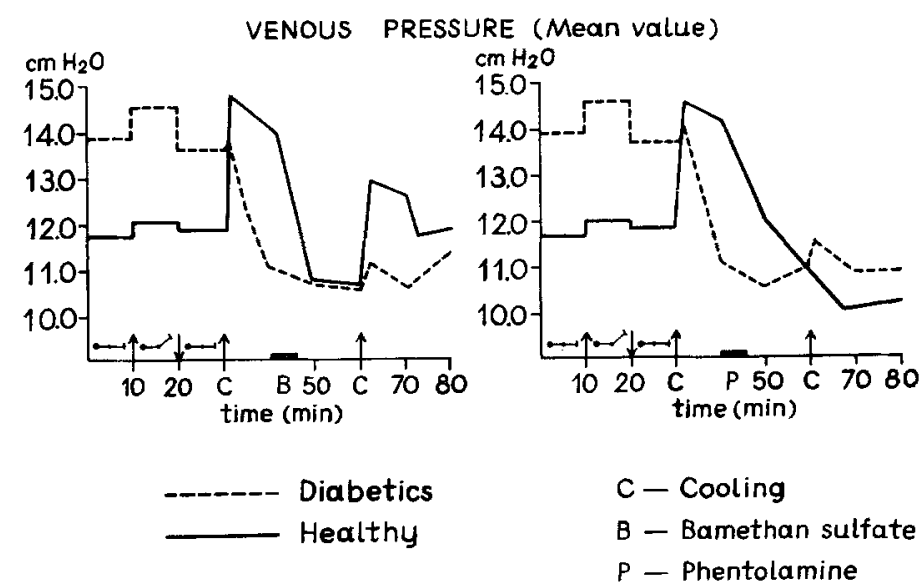

Fig. 2. Curves of the mean values of forearm blood flow in healthy subjects and diabetics obtained during different stages of the examination (for details, see text)

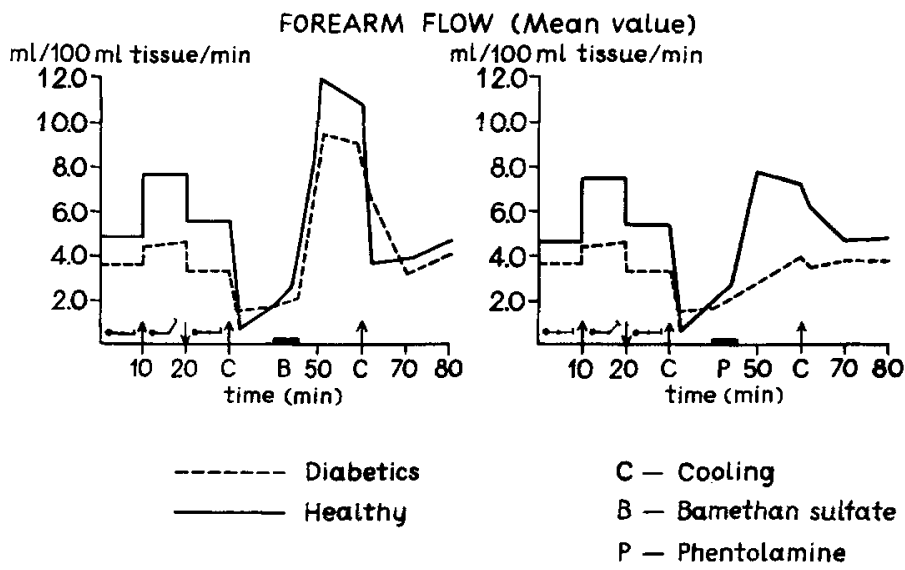

Fig. 3. Curves of the mean values of forearm venous pressure in healthy subjects and diabetics, obtained during different stages of the examination. (For details, see text)

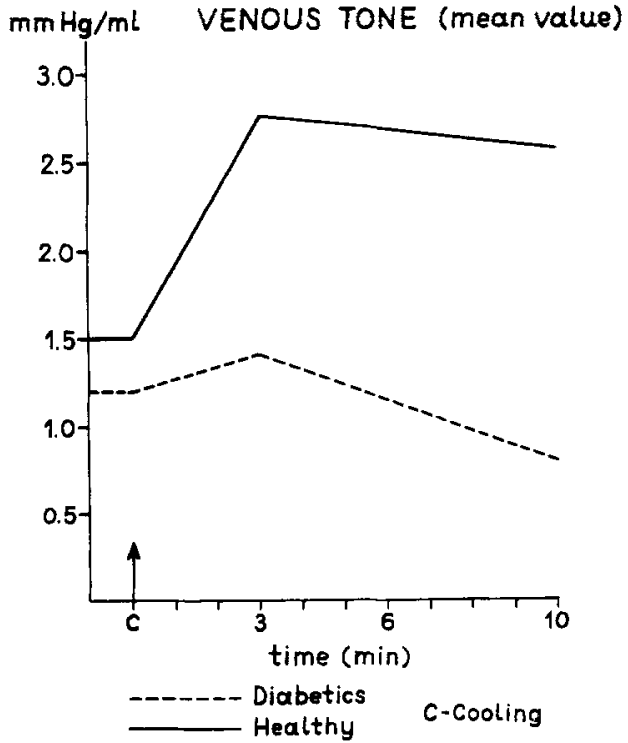

Fig. 4. Curves of the mean values of forearm venous tone in healthy subjects and diabetics after cooling of the opposite forearm
The values of venous pressure are somewhat higher in diabetics while those of the venous tone are lower than in healthy subjects. Since the venous tone $(V T)$ was calculated from the increment of the venous pressure $(\Delta P)$ and increment of the forearm volume $(\Delta V)$, the decrease in the venous tone in diabetics occurs because of the lower increment of the pressure. This was perhaps related to the anatomically weaker structure of the venous vascular walls and/or impaired adrenergic innervation. On the other hand, the somewhat higher initial values of the venous pressure in diabetes can reflect the impaired performance of the heart due to metabolic disturbances.

Among the disturbances observed in the present study, the most important one involves an impairment of the vaseular reflexes within the venous system. This statement is supported by:

1. The significantly smaller increase in the forearm blood flow after passive raising of the lower limbs in diabetics, as compared with healthy subjects.

2. The smaller rise of the venous tone after cooling in diabetics, as compared with healthy subjects. 
3. Similar changes in the measured parameters, after administration of a drug with a direct effect on the muscular coat of the vessels, in both groups. This was in contrast to the markedly weaker effect exerted in diabetics by agents blocking the alpha receptors.

An impairment or abolition of the physiological reflexes within the veins can apparently be one of the signs of the vascular changes in diabetes. The differences in the venous reflexes seen after blocking the alpha receptors may indicate that changes in the wall innervation may be the primary cause of diabetic venopathy.
4. Christensen, N.J.: Spontaneous variations in resting blood flow, postischaemic peak flow and vibratory perception in the feet of diabetics. Diabetologia 5, $171-178$ (1969).

5. Ditzel, J.: Conjunctival vascular changes in relation to retinopathy and nephropathy of diabetes mellitus. Acta med. scand. 182, 213-218 (1967).

6. Godlewski, B., Ostrowski, K.: Mikroangiopatia cukrzycowa $W$ obrazie kapilarograficznym spojówki gałkowej. Pol. Arch. Med. Wewnęt. 46, 281-286 (1971).

7. Hanke, D., Schlepper, M., Westermann, K., Witzleb, E.: Venentonus, Haut- und Muskeldurchblutung an Unterarm und Hand bei Beinarbeit. Pflügers Arch. 309, 115-127 (1969).

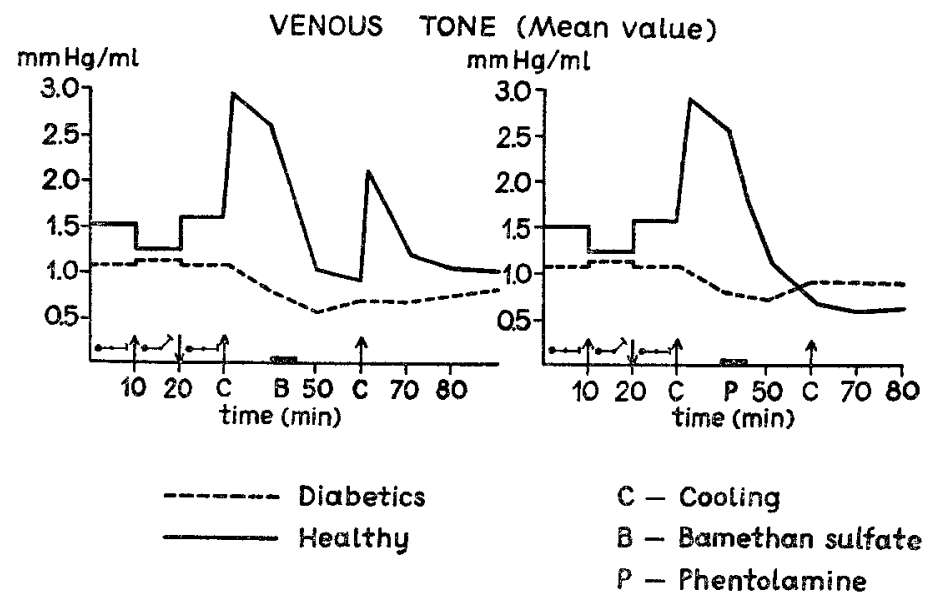

Fig. 5. Curves of the mean values of forearm venous tone in healthy subjects and diabetics, as obtained during different stages of the examination. (For details, see text)

Changes in the venous pressure and tone, as well as impairment of the reflex mechanisms are of importance not only to the capacity aspect of the venous system; they may also exert an effect on the microcirculation, particularly on the capillary exchange. The mean capillary pressure and direction of the flow of liquid between the capillary lumen and intercellular space depends on the difference in the pressures at the beginning and end of the capillary ressel (Stainly and Renkin, 1961). For this reason, even small changes in venous pressure can greatly affect the pressure in the capillaries and exert an influence on the direction of the flow of liquid in the system: vessels - tissues.

\section{References}

1. Alexander, R.S.: The Peripheral venous system. In: Handbook of physiology (Edit.: W.F. Hamilton), vol. 2, p. $1075-1098$. Washington. American Physiology Society 1963.

2. Camerini-Davalos, R.A., Caulfield, J.B., Rees, S.B., Lozano-Castaneda, O., Naldjian, S., Marble, A.: Preliminary observations on subjects with prediabetes. Diabetes 12, 508-518 (1963).

3. Chazan, B.I.: Conjunctival vascular lesions. Classification and clinical significance with special reference to diabetes. Acta diabet. lat. 6, 355-370 (1969).
8. Kaindl, F., Polzer, K., Schuhfried, F., Tiso, B., Weindinger, P.: Clinical value of venous tone and venous capacity measurement. Angiology 20, 256-260 (1969).

9. Landau, J., Davis, E.: The small blood vessels of the conjunctiva and nailbed in diabetes mellitus. Lancet 1960 II, $731-734$.

10. Sharpey-Schafer, E.P.: Venous tone: effects of reflex changes, humoral agents and exercise. Brit. med. Bull. 2, 145-148 (1963).

11. Shlomo, L., Samueloff, B., Sture, B., Shepferd, J.T.: Temporary arrest of circulation to a limb for the study of venomotor reactions in man. J. appl. Physiol. 21, $341-346$ (1966).

12. Skovborg, F., Nielsen, Aa.V., Lauritzen, E., Hartkopp, O.: Diameters of the retinal vessels in diabetic and normal subjects. Diabetes 18, 292-298 (1969).

13. Stainby, W.N., Renkin, E.M.: Autoregulation of blood flow in resting skeletal muscle. Amer. J. Physiol. 201, 117-122 (1961).

14. Tatoń, J.: Angiopatia cukrzycowa. Warszawa: PZWL 1968.

15. Wood, J.E.: The veins. Normal and abnormal funetion. Boston: Little, Brown and Co. 1965.

Professor A. Czyżyk

Department III of Internal Diseases

Medical Academy

ul. Lindleya 4

Warsaw, Poland. 